\title{
The Ecology of Rawa Aopa, a Peat-swamp in Sulawesi, Indonesia
}

\author{
by
}

\author{
ROBERT ZWAHLEN, Dr phil. nat. (Bern) \\ Ecosens AG, Environmental Management Consultants, \\ PO Box 121, Fabrikweg 2, \\ CH-8306 Bruttisellen/Zürich, Switzerland.
}

\section{INTRODUCTION}

In contrast to the neighbouring Kalimantan, the mainly mountainous Sulawesi (the former Celebes) is not rich in wetlands, and according to Whitten et al. (1987), Rawa Aopa is the only peat-swamp in Sulawesi. Although the swamp is still intact, it is coming under pressure as the surrounding forests are cleared to make way for new settlements as part of Indonesia's transmigration programme.

The information presented here stems mainly from field-work ( $c f$. Zwahlen, 1989) and from a series of unpublished and therefore not readily accessible reports. The paper aims at giving some indications for the sustainable development of this area.

\section{GeNERAL StTUATION}

\section{Location}

Rawa Aopa lies in South-east Sulawesi, around $70 \mathrm{~km}$ west of Kendari, the capital of the province (Fig. 1). The Aopa Depression is a part of the drainage basin of the Konaweha/Lahumbuti/Sampara Rivers system.

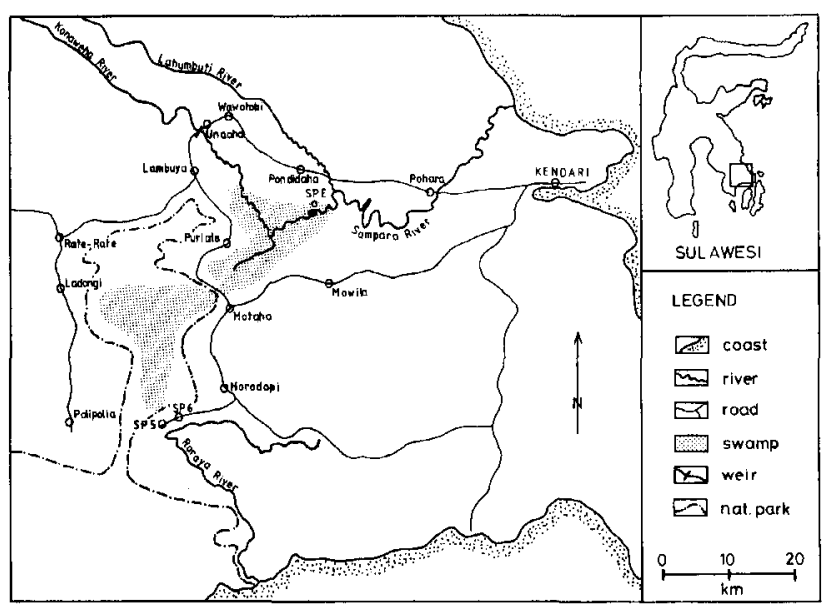

FIG. 1. Location of study area in South-east Sulawesi.

\section{Climate}

Southeastern Sulawesi is characterized by a slightly seasonal climate, with a wet season lasting from January to July, and a drier season extending from August to December. The annual precipitation is approximately $1,400 \mathrm{~mm}$ and the average yearly temperature is $26.1^{\circ} \mathrm{C}$, with little daily or yearly variation.

\section{Topography}

The swamp lies at about $20 \mathrm{~m}$ above sea-level and is surrounded by hills and mountains. Except in its southernmost parts, the limits of an ancient lake and its surrounding terraces are quite conspicuous, being marked by both a changing slope and a distinct change in the vegetation. The southern and the northern parts of Rawa Aopa are connected by a very narrow gap near Motaha ( $c f$. Fig. 1).

\section{Hydrology}

The study area is part of the river basin of the meandering Rivers Konaweha and Lahumbuti, which join at Wawolemo to form the Sampara. The Aopa catchment has a total area of approximately $1,700 \mathrm{~km}^{2}$, of which approximately $300 \mathrm{~km}^{2}$ are seasonally flooded. Occasional floods of the Konaweha River cause damage to the newly-created irrigations in the Wawotobi plain. During the period of record of river flows (1981 to 1987), three such events have occurred.

There is some exchange of waters between the Rivers and the swamp, either as floodplain flow (i.e. spilling over the rivers' banks at high water-levels) or through the three 'mouths' of Rawa Aopa. There is no sufficient database to quantify the amount of these flows, and therefore the role of Rawa Aopa in relation to the floods, but it can be assumed that, at least under certain circumstances, the flows have a flood-attenuating effect. For 1983 - the one year of records of all the three existing gauging stations the net outflow from Aopa to the Konaweha is estimated to have been 510 million $\mathrm{m}^{3}$. This corresponds to an average outflow rate of $16 \mathrm{~m}^{3} / \mathrm{sec}$ throughout the year.

Soils

The Konaweha River-banks are higher than the adjacent parts of the plain, and are mostly cultivated. They do not seem to be flooded every year, but only during extremely high floods. The silty or clay soils of the Wawotobi plain are not easily percolated. This leads to water covering the ground in slight depressions even during the dry season. In parts of the swamp, the mineral sediments are overlain by peat.

\section{THe NATURAL ENVIRONMENT}

\section{Vegetation}

\section{a. Existing Information}

A series of reports (Anon., 1978, 1983, 1985a, 1985b) give some information about the vegetation of the Rawa Aopa-Watumohai National Park. However, these reports 
are concerned predominantly with vegetation-types which do not occur within the swamp itself, namely montane forest, savanna, and mangrove forest. Apparently, only one botanical study of the Aopa swamp itself has been carried out so far. Unfortunately, only a preliminary report emanated from that study (Jacobs, 1978), giving very summarized information about the vegetation of Rawa Aopa.

\section{b. Distribution of Vegetation Types}

The vegetation map shown in Fig. 2 was drawn from 1982 aerial photographs on the scale of approximately $1: 100,000$. Field trips served to verify the identification of the vegetation types. At the scale given here, it has to be a

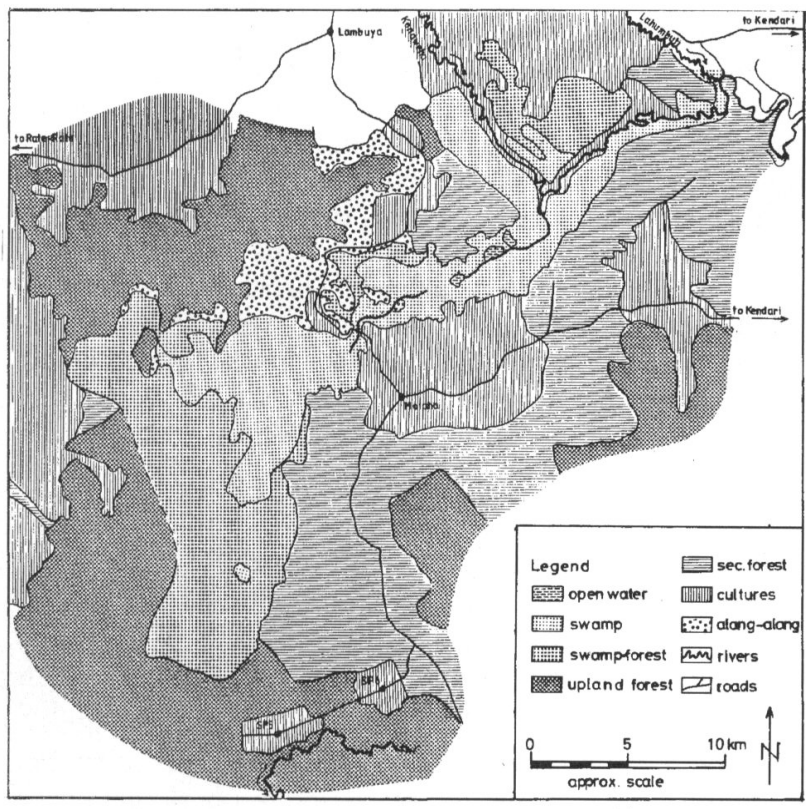

Fig. 2. Vegetation map of the study area. Only a few of the villages shown in Fig. I are mentioned here for orientation. Encroachment on primary forest is clearly visible. SP 5 and SP 6 are newly-created transmigration villages. A description of the vegetation-types is given in the text.

rather generalized map - especially because of the very small-scale mosaic of different vegetation types present in many areas. In certain places, most obviously in the region south of Rate-Rate and close to the southwestern border of the swamp, large parts of the forest have been cleared recently to make way for new settlements and areas of cultivation. Therefore, the map does not always reflect the actual situation. A short description of the vegetation types follows.

Open water:- Open water forms narrow passages or small shallow lakes up to a few hectares in extent. Their beds are covered by a thick layer of litter, forming the characteristic peat. This indicates anaerobic conditions in the water adjacent to the bottom. Only the larger 'lakes', which are visible in the aerial photographs, are shown in Fig. 2.

Swamp vegetation:- This characterizes all parts of the open swamp. There are two main vegetation-types. One is dominated by plants that are rooted in the ground and of which the leaves float on the water's surface. The dominant species are Nymphoides indica and the Lotus, Nelumbium nelumbo. Some submerged plants are also found (e.g. Utricularia sp.), as well as floating plants without roots in the ground (Eichhornia and Pistia). Large parts of the swamp are covered by thick mats of floating vegetation (Fig. 3). Three unidentified plant species dominate: a grass forming low but very dense mats, a sedge ( $c f$. Cyperus sp.) $1 \mathrm{~m}$ or more in height, and a large fern ( $c f$. Stenochlacna sp.). These mats are mixed with reeds rooted in the ground and a large grass of the Phragmites type.

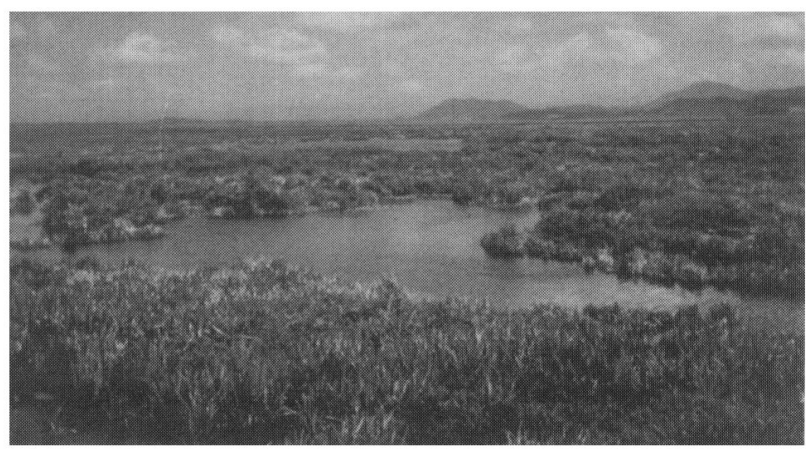

FIG. 3. Mats of floating vegetation, a typical aspect of the swamp. Southwestern part of Rawa Aopa, view from the observation tower near the bridge over the swamp, looking westward. The hills bordering the swamp are covered with forest, the white patches are stands of Alang-alang (Imperata cylindrica). This section of Rawa Aopa is part of the National Park.

Swamp-forest:- Different types of swamp-forest dominate towards the edges of the swamp, where the water is less deep (generally much less than $1 \mathrm{~m}$ ), but where the soil is waterlogged or covered by water for an extended period every year. Climbers are very abundant, and include rattan palms (Calamus spp.) and a pitcherplant (Nepenthes sp.). Large pandans are frequent. At the outer edges of the swamp, or along swampy creeks leading to it, there are Sago Palms (Metroxylon sagu), although this palm is very rare in the southwestern part of the swamp. In some places the talipot palm (Corypha cf. elata) is found. In the northeastern part of Rawa Aopa, there is less swamp-forest - formed predominantly of smaller trees, with a quite open canopy and thick undergrowth (Fig. 4); in the southwestern part, the forested area is much more extensive and the forests are composed of larger trees. In this area, it is not always possible to make a clear distinction between swamp-forest and upland forest, as there is a gradual merging of one into the other. The boundary between them has therefore been drawn rather arbitrarily.

Primary upland forest:- The transition of lowland into montane forest is too gradual to be shown on our map; besides, it has not been of prime interest for the purpose of this study. In some places, this so-called primary forest may actually be composed of older stands of secondary forest. Lowland primary forest is not subjected to the direct influence of the swamp, although some parts of it may be flooded irregularly for short periods of exceptionally high water-level. Large trees form a closed 


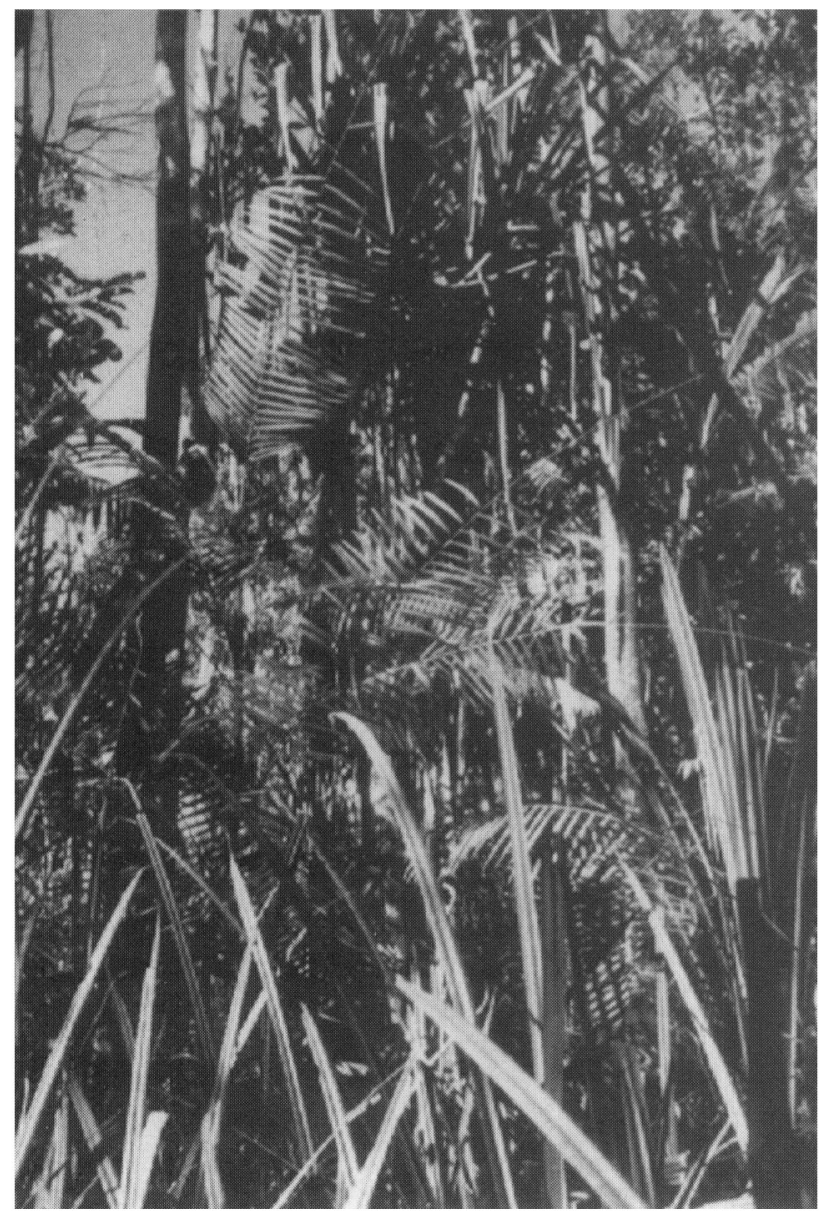

FIG. 4. Typical aspect of the swamp-forest in the northeastern part of the swamp, close to Puriala. The trees are only about $8 \mathrm{~m}$ high and do not form a closed canopy. Large pandans (top centre) and rattan palms (Calamus sp., centre) are abundant. The soil is covered by thick stands of a sedge about $2 \mathrm{~m}$ in height (foreground).

canopy, shading out the undergrowth, which is therefore less dense. There are many climbers here, among them different kinds of rattan palms (species of Calamus, Korthalsia, and probably others), together with various other small palms (Livistona rotundifolia, Caryota mitis, and the very frequent Licuala celebensis). Only small patches of this forest type remain intact, large areas having already been cleared to make way for agricultural land, either in the form of shifting cultivation (slash-andburn) or for irrigated fields. Montane forest on gentler slopes has also been destroyed by slash-and-burn practices, but especially on steeper slopes and at higher elevations, large areas of forest still remain intact.

Secondary forest predominant:- This constitutes a very small-scale mosaic of different types of upland vegetation, with secondary forest in different stages (bushland, bamboo thickets, and snatches of forest of different ages). Interspersed with this secondary forest are settlements and cultivated areas (see below), though small scattered patches of primary forest still remain. Along small creeks there is swamp vegetation, often dominated by Sago Palm. This mosaic types is very extensive, especially along the eastern edge of the Aopa Depression.
Cultivated areas predominant:- This mosaic contains much less forest or bush vegetation than the preceding one. Settlements with the typical house-gardens characterized by Coconut Palms (Cocos nucifera), rainfed cultures (ladang), and irrigated cultures (sawah), occupy the larger part of the surface. Shifting cultivations surround Rawa Aopa and are especially frequent to the south-east of the swamp (Mowila-Motaha-Horodopi). Permanent cultures occur, e.g. on the levees of the Konaweha, though there is no gallery forest left along this River within the study area. Irrigated cultures are present mainly to the north and west of the study area (Wawotobi plain, Lambuya, Rate-Rate, and southwards). Further irrigation projects are being realized or studied, e.g. on the Konaweha River's right bank (EWI, 1988a). Small patches of secondary forest and of Alang-alang (see below) occur.

Alang-alang:- Large stretches of land, especially hill slopes that are too steep for cultivation, where the original forest has been cleared, are covered by a vegetation-type made up practically of one grass species, the Alang-alang or Lalang (Imperata cylindrica). This coarse grass is eaten, when young, by cattle, so surfaces covered with Alang-alang are kept in that state by regular burning. As young trees are killed by these grass fires, natural reforestation is impeded.

\section{Fauna}

Whereas the fauna of Sulawesi as a whole is reasonably well known, there is very little specific information available about the Aopa Depression. Some observations have, however, been made in the area in relation to the creation of Rawa Aopa-Watumohai National Park (Anon., 1978, 1983), though not specifically for the swamp.

\section{a. Mammals}

A list of the most important mammal genera and species of Sulawesi is given by Groves (1976). No mammals were observed during my field trips. According to the above-mentioned reports, the following species of large mammals are present in the Aopa Depression: Babirousa babyrussa (Babirusa, endemic), Sus verrucosus (Wild Boar or Wild Pig, introduced to Sulawesi), Anoa (Bubalus) depressicornis (Lowland Anoa, endemic), Bubalus bubalis (feral Water Buffalo, introduced), Cervus timorensis (Deer, introduced), Tarsium spectrum (Tarsius, indigenous), and Macaca ochreata (Black Macaque, endemic).

\section{b. Birds}

There is no field guide for Sulawesi available, and so for indentification of birds I had to rely on J. MacKinnon (1988) and Stresemann (1939). Forty-four different species of birds were identified during my field trips, 27 of them in the open parts of Rawa Aopa (Table I). This list is certainly not complete: thus some smaller species of rails were seen but not identified, and some of the species mentioned in various reports (Anon., 1978, 1983), e.g. Fulica atra, Gallicrex cinerea, Ardea cinerea, and 
Pelicanus conspicillatus, were not seen by me. However, it is obvious that Rawa Aopa is a wetland with an interesting and diversified avifauna (Fig. 5).

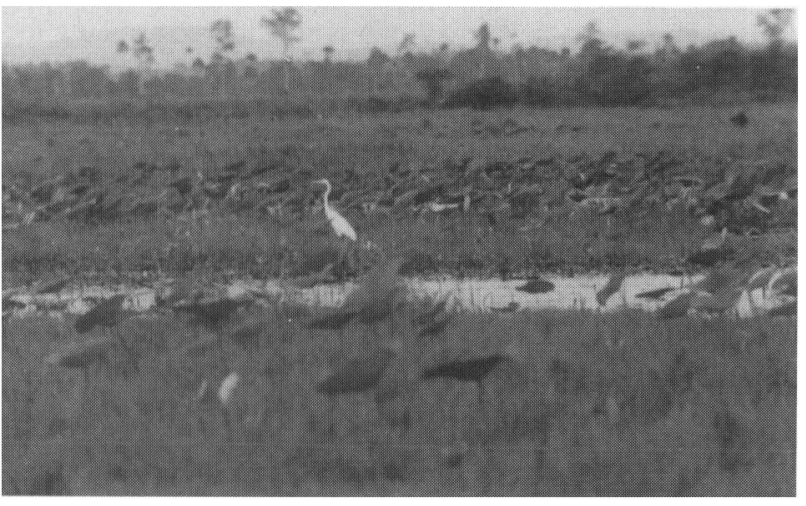

FIG. 5. Great Egret (Egretta alba) in the northeastern part of the swamp. The water is largely covered by floating mats of a lowgrowing grass. Lotus (Nelumbium nelumbo) leaves are very conspicuous. This part of Rawa Aopa is not within the National Park.

\section{c. Reptiles}

Three large reptile species are reported to occur in the study area, namely Crocodylus porosus (Estuarine Crocodile), Python reticulatus (Reticulated Python), and Hydrosaurus amboiensis (Sailfin Lizard). Neither pythons nor crocodiles were seen during the field-work for this study, but the Sailfin Lizard (Fig. 6) is quite frequent and can easily be observed from a boat on the Konaweha River. On one occasion, eight adult and five juvenile Sailfin Lizards were seen during a boat-ride from Wawotobi weir downstream to SP E (cf. Fig. 1), and a similar number on another occasion between SP E and the mouth of Lawe Aopa. In spite of its still quite large numbers, the Sailfin Lizard's habitat is obviously shrinking. It does not occur in the vicinity of human habitations, and it needs intact vegetation along the riverbanks, preferably with trees hanging over the water which are used for basking. However, there are not many trees left on the river banks, and much of the remaining natural vegetation along the rivers is burned during the dry season. The Sailfin Lizard appears to be absent from the swamp itself.

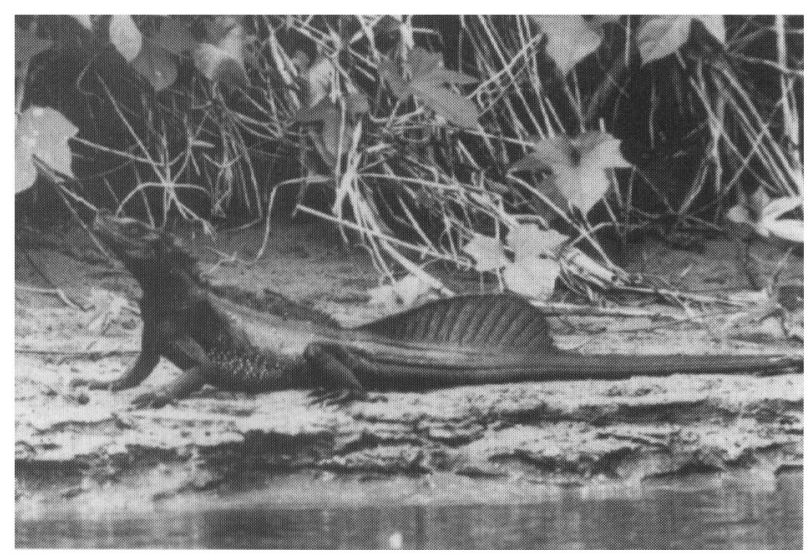

FIG. 6. A large male of the Sailfin Lizard (Hydrosaurus amboiensis) basking on the bank of Konaweha River.
TABLE I

List of Bird Species Observed During Field-work.

\begin{tabular}{lllllllll}
\hline Group and & \multicolumn{1}{c}{ Locations* } \\
Name of Species & 1 & 2 & 3 & 4 & 5 & 6 & 7
\end{tabular}

Phalacrocoracidae, Cormorants

Phalacrocorax melanoleucus

$P$. sulcirostris

Anhinga melanogaster

Ardeidae, Herons

Ardea sumatrana

A. purpurea

Ardeola speciosa

Bubulcus ibis

Egretta sacra

E. alba

E. intermedia

E. garzetta

Nycticorax nycticorax

Ixobrychus sp.

I. cinnamomeus

Buteroides striatus

Ciconiidae, Storks

Mycteria cinerea

Anatidae, Ducks

Dendrocygna sp.

Anas superciliosa

Accipitridae, Hawks and Eagles

Elanus caeruleus

Haliaetus leucogaster

Accipiter sp.

Haliastur indus

Rallidae, Rails

Amaurornis phoenicura

Gallinula chloropus

Prophyrio porphyrio

Jacanidae, Jacanas

Irrediparra gallinacea

Scolopacidae, Snipes

Actitis hypoleucus

Columbidae, Pigeons

Crytophaps poecilorhoa

Geopelia sp.

Ducula bicolor

Cuculidae, Cuckoos

Centropus bengalensis

Apodidae, Swifts

Apus sp.

Alcedinidae, Kingfishers

Alcedo atthis

A. meninting

Halcyon chloris

Meropidae, Bee-eaters

Merops superciliosus

Bucerotidae, Hornbills

Rhyticeros cassidix

Passeres, Songbirds

Hirundo tahitica

Oriolus chinensis

Corvus enca

Acrocephalus arundinaceus

Cinnyris serica

C. jugularis

Coracias sp.

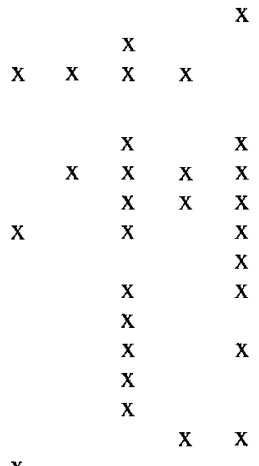

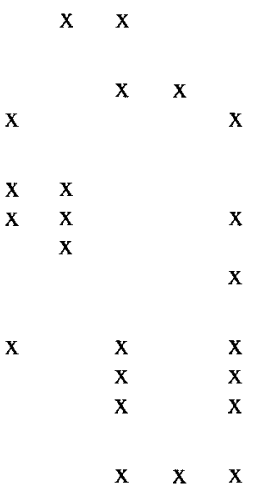

$\mathrm{X}$

$\mathbf{X}$

$\mathrm{x}$

$x$

$\mathrm{X} \quad \mathrm{X}$

$\mathrm{X}$

* Locations: 1 = Konaweha River; 2 = Wawotobi plain; $3=$ Rawa Aopa, northeastern part; $4=$ Rawa Aopa, central part (near bridge at Desa Aopa); $5=$ Rawa Aopa, southwestern part (National Park); $6=$ Swamp-forest, north-east; 7 = Swamp-forest, south-west (National Park). 


\section{d. Fishes}

No inventory of fish species of the rivers and the swamp is available. The most abundant species within the study area (or at least those species that are normally caught by fishermen) are Puntius javanicus, Trichogaster pectoralis, Channa (Ophiocephalus) striatus (Snakehead), and Clarias batrachus (Walking Catfish). All these species are not native to Sulawesi, but have been introduced by Man. The Puntius is fairly abundant in the rivers, and the three other species occur in the swamp. Not surprisingly, these three have additional respiratory organs that allow them to breathe atmospheric oxygen when the oxygen content in the water is low, which is likely to be the case during most of the year at least in some parts of the swamp, and is definitely so in the stagnant low water in the dry season.

\section{e. Other Fauna}

Insects are very frequent and occur in large numbers. Dragonflies and butterflies are the most striking, the latter especially in the forests.

Two freshwater molluscs have been recorded as consumed by the local population. One is a large snail (Vivipara type, with a shell height of 6-8 cm), heaps of the shells of which have been seen close to houses on the Konaweha River banks. The other species is a freshwater (or possibly brackish water) clam that is caught in the Sampara River downstream of Pohara.

CLU $(1989 a, 1989 b)$ has recorded some zooplankton species from the study area. Otherwise, the invertebrate fauna of Rawa Aopa is scarcely known at all.

\section{Threatened Species and Conservation}

According to Whitten et al. (1987), Goodwin \& Holloway (1978), and Honegger (1968), the following species that have been observed or reported to live in the study area are considered as being rare and endangered:

- Tarsius spectrum (Sulawesi Tarsier)

- Babirousa babyrussa (Babirusa)

- Anoa depressicornis (Lowland Anoa)

- Anoa quarlesi (Mountain Anoa)*

- Mycteria (Ibis) cinereus (Milky Stork)

- Macrocephalon maleo (Maleo)*

- Crocodylus porosus (Estuarine Crocodile)

This clearly supports the view expressed by J. \& K. MacKinnon (1986), that Rawa Aopa is one of the priority areas for the protection of Nature in Sulawesi.

\section{Rawa Aopa-Watumohai National Park}

The Rawa Aopa-Watumohai National Park was declared in 1987 (Anon., 1985a, 1985b, 1987); it was an extension of the already existing Watumohai National Park, bringing it to a total surface of 105,194 ha. By this extension, the proposition made by FAO (1982) has been at least partly followed. The Park contains a variety of different habitats and vegetation-types, namely montane and lowland forest, wetlands, swamp-forest, savanna, and

* Species reported to live in montane forest close to Aopa
Depression. mangrove forest. According to Ledec \& Goodland (1988), lowland primary forests, especially in the southern peninsulas of Sulawesi, need special protection, as only relatively small undisturbed patches of these forest types remain. Rawa Aopa is considered as being the most important area for conservation purposes in southeastern Sulawesi, and one of the six most important areas in the whole of Sulawesi (J. \& K. MacKinnon, 1986). The existing Rawa Aopa-Watumohai National Park includes only the southern part of the swamp (see Fig. 1).

\section{HUMAN ENVIRONMENT}

\section{Population}

Indonesia has made great efforts to reduce the overall population growth-rate and at the same time to improve the health condition of the population (DEH, 1989). A successful family planning programme was started in 1982, and Indonesia participates in the WHO-based project 'Health for all by the year 2000 '.

The total population in the project area, which includes six Kecamatan (sub-districts) of Kabupaten (district) Kendari and one Kecamatan of Kabupaten Kolaka, was 147,821 in AD 1988. 55.4\% of the population are within the productive age-class (15 years and older) and $44.6 \%$ are younger than 15 years of age; only $1.4 \%$ are older than 64 (Kantor Statistik Kendari, 1989). Annual population growth in the project area has been $4.0 \%$ over the last 5 years. This is clearly above the nationwide average, which was $2.4 \%$ in 1988 . An especially high population growth has taken place in Kecamatan Ladongi of Kabupaten Kolaka ( $10.2 \%$ on average). This reflects the population development due to the creation of new transmigrant settlements.

\section{Agriculture}

Approximately $80 \%$ of the population in the project area work in agriculture (EWI, 1988b, 1988c; CLU, $1989 a, 1989 b$ ). Rice is the most important subsistence crop, along with maize. Other cultivations (of cloves, cocoa, coffee, cashew, and pepper) are cash-crops. Coconuts, bananas ( $M u s a$ spp.), and a variety of other fruits, are produced and partially sold on local markets. Livestock (cattle, Water Buffaloes, and goats) is an important resource (of draft animals, income, and food).

\section{Fishing}

Only a few people in the area depend on fishing as their main source of income. However, many people do some fishing for their own consumption. Yields in the Aopa area seem to vary greatly from year to year, but are roughly between 100 and 280 tons/year. The reasons for this variation are not clear, though different factors might add to it (e.g. fluctuations in fish populations, differences in catching effort, and incomplete reporting of catches). This total catch is quite low (see Table II) compared with other lakes elsewhere, but with the low nutrient-content that is characteristic of peat-swamps, only a low productivity is to be expected. 
TABLE II

Catch of Fishes, Area, and Catch per Unit Area, in Some Indonesian Reservoirs (Welcomme, 1979) as Compared with Reported Catch for Rawa Aopa.

\begin{tabular}{lccc}
\hline Reservoir & $\begin{array}{c}\text { Catch } \\
\text { in Tons }\end{array}$ & $\begin{array}{c}\text { Area } \\
\mathrm{km}^{2}\end{array}$ & $\begin{array}{c}\text { Catch/Area } \\
\mathrm{kg} / \mathrm{ha}\end{array}$ \\
\hline Jaitiluhur & 180 & 83.0 & 21.7 \\
Pening & 709 & 22.0 & 322.5 \\
Dorma & 111 & 4.0 & 277.5 \\
Jombor & 38 & 1.9 & 202.1 \\
Pacal & 138 & 3.9 & 356.6 \\
Prijetan & 11 & 2.3 & 49.1 \\
Sentir & 3 & 0.7 & 49.1 \\
Kalen & 2 & 0.5 & 39.1 \\
\hline Rawa Aopa & $100-280$ & $90-240$ & 11 \\
\hline
\end{tabular}

\section{Other Natural Resources}

Hunting:- Anoa and Babirusa are said to be hunted but, due to their rareness and secretive habits, these species probably do not play a major role in the local economy. The most frequent game species is the Wild Pig (Sus verrucosus), which is also likely to cause damage to crops. During field-trips, captured or shot Wild Pigs were seen on several occasions. This animal, however, is eaten only by the non-islamic minority of the population.

Sago:- Sago Palms (Metroxylon sagu) have been introduced to Sulawesi, being frequent in the project area - especially along small, swampy streams flowing to the swamp. In some places, they also grow along the edges of the swamp itself, and they are numerous along the backswamps behind the Konaweha River banks. In the southwestern, more densely forested parts of Rawa Aopa, Sago Palms are quite rare. The densest stands can be found close to villages whence sago is exploited. Sago is utilized by the local Tolaki population (Levine, 1981).

The Sago Palm is a very useful plant, although its utilization is declining. It grows in swampy areas that are, very often, not suitable for cultivation. One mature Sago Palm stem yields 150 to $300 \mathrm{~kg}$ of crude starch, with a starch content of about 50\% (Corner, 1966; Whitmore, 1977; Franke, 1981). The yield from one or two palm stems is sufficient to cover the carbohydrate needs of a family of four for one year. The life-span of an individual palm is approximately 15 years, and it has to be cut just before flowering, i.e. at an age of 11 to 15 years, to obtain the maximum yield.

It can be estimated that a stand of Sago Palms of about 0.1 ha would produce the necessary starch for a family on a sustained basis, without requiring any input of fertilizers or pesticides, and with a minimum of effort. Most sago exploitation is done for subsistence. Along the lower Sampara, however, Sago is exploited on a commercial basis, the product being sold on local markets. Besides starch, Sago Palms provide a very good thatching material, which will last for up to seven years.

Wood:- Timber can be found in the different types of upland forest. The swamp-forest, according to Davidson (1987), contains no valuable timber species. However, at least three kinds of rattan palms (species of Calamus, Korthalsia, and possibly other genera) grow in the swamp-forest and are exploited. As opposed to timber extraction, harvesting of rattan does not seem to have major negative impacts on primary forests. Therefore, rattan can be considered as a permanently exploitable, regenerating natural resource. According to Myers (1988), revenues obtained from rattan in Indonesian forests amount to 90 million US\$ annually. Secondary forests are the main producers of firewood, which is the most important fuel in the villages of the project area. Most people seem to gather their own firewood, although there is a small-scale trade in this resource.

There is a fair variety of other products obtained from forests and other natural vegetation-types in the area studied. Many different plants are utilized, mostly for local consumption or use. However, some products are sold or even exported. In 1981, the total value of nontimber forest products of Indonesia attained 200 million US\$. Up to now, only a fraction of possibly valuable plant species are being exploited, and further research is likely to reveal a large variety of other potentially useful plants - especially for drugs and pharmaceuticals (Haryono, 1985; UNEP, 1987; Whitmore, 1987; Myers, 1988).

\section{Tourism}

Currently, tourism plays a very minor role in the economy of south-east Sulawesi. However, there seems to be a potential for developing it. Besides cultural attractions, it is mainly natural richness and beauty that attract tourists. Therefore, these factors have to be considered as a potentially important resource. The swamp (bird-watching, etc.) could become a tourist attraction of this region.

\section{Water-supply}

Contaminated drinking-water is a cause of diseases especially of the gastro-intestinal tract. Diarrhoea is a very frequent disease and an important cause of mortality. In a survey of 43 local water-supply facilities (Setiady, 1979), 17 proved to be contaminated with Escherichia coli, and all of them contained coliform germs. This is an indication of inadequate disposal of human wastes.

\section{Food}

The nutritional status of the local population seems to be good. A wide variety of foods are eaten, especially different kinds of vegetables and fruit, in addition to the staple diet which is rice in most cases. The main protein source is chicken; but fish, other meat, and soybeans, can be important.

\section{Health}

Malaria, water-borne diseases (gastro-intestinal infections and diarrhoea), and infections of the respiratory tract, are very frequent and are the main causes of mortality. Diarrhoea is closely related to hygienic conditions; its prevalence is therefore influenced strongly by the quantity, and especially the quality, of the drinking-water.

Intestinal parasites are a major health-problem. Some can be very harmful or even fatal, such as hookworms or Entamoeba histolytica. Most of these parasites are transmitted indirectly from one person to another by means of 
drinking-water or food being contaminated by human wastes. The figures in Table III indicate a high prevalence of some of these parasites in Sulawesi.

TABLE III

Frequency of Important Intestinal Parasites in Sulawesi. (Setiady, 1979.)

\begin{tabular}{|c|c|c|c|c|}
\hline \multirow[t]{2}{*}{ Parasite } & \multicolumn{2}{|c|}{$\begin{array}{c}\text { Indigenous pop. } \\
\text { Positive: }\end{array}$} & \multicolumn{2}{|c|}{$\begin{array}{l}\text { Transmigrants } \\
\text { Positive: }\end{array}$} \\
\hline & Total & $\%$ & Total & $\%$ \\
\hline Entamoeba histolytica & 74 & 5.8 & 85 & 6.3 \\
\hline E. coli & 153 & 12.1 & 178 & 13.1 \\
\hline Endolimax nana & 1 & 0.1 & 6 & 0.4 \\
\hline Ascaris lumbricoides & 858 & 67.6 & 864 & 63.6 \\
\hline Trichuris trichiura & 308 & 24.3 & 257 & 18.9 \\
\hline Hookworms ( 2 genera) & 234 & 18.4 & 312 & 23.0 \\
\hline Oxiuris vermicularis & 4 & 0.3 & 7 & 0.5 \\
\hline Hymenolepis nana & 1 & 0.1 & 0 & 0 \\
\hline Total people examined & \multicolumn{2}{|c|}{1270} & \multicolumn{2}{|c|}{1353} \\
\hline
\end{tabular}

No Taenia saginata or $T$, solium has been reported.

\section{Malaria}

Malaria is the most important water-related vectorborne disease and has a high mortality-rate. As it is transmitted by mosquitoes (Anopheles spp.) that depend on standing water for their development, malaria is closely related to irrigation, floods, and drainage problems.

General situation:- Prior to mosquito eradication programmes, in Indonesia as many as 30 million cases occurred per year, with 1 million deaths caused by malaria annually (Kondrashin \& Rashid, 1987). The overall situation has improved since then, as large-scale malaria control programmes have been established. The most dangerous of the malaria parasites, Plasmodium falciparum, causes less than $10 \%$ of the malaria cases reported in Indonesia (Stuerchler, 1981). Cases of chloroquinineresistant $P$. falciparum have been recorded from Kalimantan, Irian Jaya, and South Sulawesi. Population movements and other activities linked to transmigration projects have in some cases led to malaria outbreaks.

Situation in the project areas:- In Kabupaten Kendari, $20 \%$ of the malaria cases are caused by Plasmodium falciparum and $80 \%$ by $P$. vivax. A malariometric survey in transmigration villages in 1989 showed a generally low infection-rate, but in one case no fewer than $25 \%$ of the infants and 5\% of the children up to 9 years of age were infected (Division of Health Planning, Kendari).

In a survey carried out in 1978,14 species of Anopheles were found in the transmigration areas around Kendari (Setiady, 1979). Swamps (and in this case the Aopa swamp) are breeding places for mosquitoes especially their borders where there is shallow water. Most villages in the study area are far enough away from the swamp to prevent a major malaria risk from this source (a distance of 1.5-2 km between settlements and mosquito breeding-places is adequate to reduce the incidence of malaria). Poor drainage of irrigated fields (a major problem in Wawotobi plain), is probably a more important source of malaria infection. The borrow-pits created for the construction of the flood-dykes, which are very numerous and contain water all-year-around, present a special problem, as they are normally not connected with the drainage system. Fig. 7 presents some indications for the relation of malaria with the drainage problem in the Wawotobi plain in 1987.

\section{Malaria 1987} New cases in Kabupaten Kendari

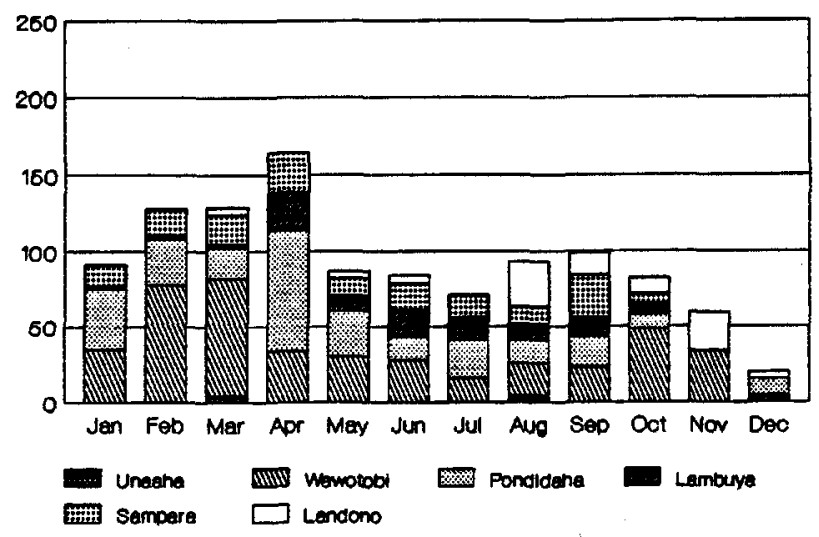

FiG. 7. Monthly distribution of new cases of malaria in the Kecamatan (sub-districts) close to Rawa Aopa. The high incidence in Wawotobi and especially Pondidaha Kecamatans, which share between them the so-called Wawotobi plain between the Rivers Konaweha and Lahumbuti, shows that the poor drainage of the newly-created irrigation schemes provides suitable breeding places for mosquitoes.

\section{Other Vector-borne Diseases}

A number of further diseases are related to water, as the agent is carried by, and/or develops in, aquatic intermediate hosts.

Schistosomiasis (Bilharziasis) is absent from Indonesia with the exception of a focus in Central Sulawesi (Stuerchler, 1981; Whitten et al., 1987). In fact, the parasite (Schistosoma japonicum) and a species of intermediate host snail (Oncomelania hupensis) have been found in the Napu valley and in Lake Lindu. A further spreading of the disease seems to have been prevented by the fact that this intermediate host does not live below approximately $1,000 \mathrm{~m}$ above sea-level.

Filariasis, another parasitosis carried by mosquitoes, is rather widespread and frequent in the project area. There are two microfilarian parasites present, Brugia malayi and Wuchereria bancrofti, causing elephantiasis. Only the former species is rather frequent within the study area.

\section{INTERACTIONS}

The main interactions of the swamp with its surroundings are illustrated in Fig. 8. The human population plays a major role, as its activities are responsible for environmental changes, occurring nowadays at an ever-more-rapid pace. Until very recently, the native Tolaki population seems to have lived in balance with its environment. Upland and montane forests as well as the different parts of the swamp were utilized on a sustained basis. Sago was the staple food, and rice seems to have been of minor importance. There was enough space for allowing shifting cultivation without complete exhaustion of soils. 
Rawa Aopa

interretations with surroundings

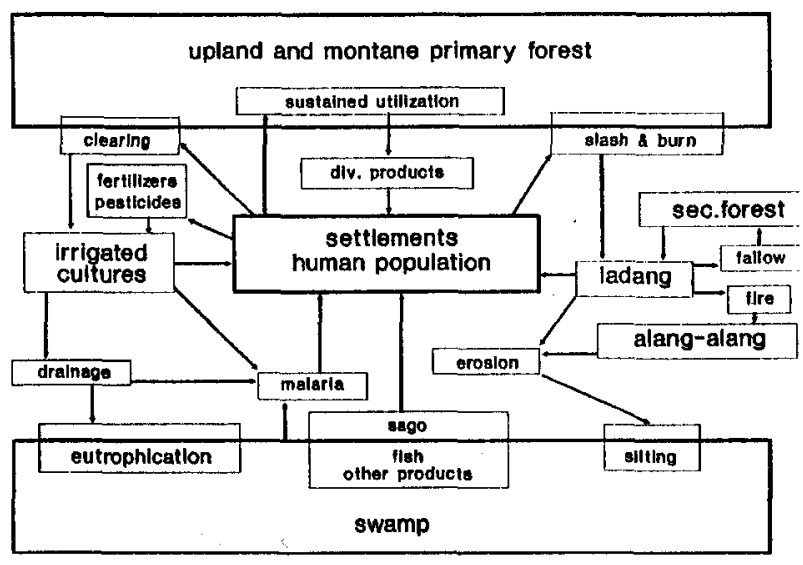

FIG. 8. Interrelations between Rawa Aopa and its surroundings. The transformations brought about by the expanding human population affect the forests surrounding the swamp and lead indirectly to an increased pressure on the swamp.

The increasing population, and mainly the creation of transmigrant villages inhabited by Javanese and Balinese, have now changed the system. The destruction of primary forests is increasing, and steeper slopes than formerly are being cleared. Large surfaces are kept open by regular burning and use as pastures for cattle. The surfaces which are not covered by forest are prone to erosion especially the steeper ones. In different parts, particularly between the Rivers Konaweha and Lahumbuti and on the right bank of River Konaweha, irrigation systems for the cultivation of rice have been constructed, and others are planned or under construction.

All the above activities lead to an increase in the silting up of Rawa Aopa. Fertilizers, brought to the swamp by drainage water from irrigated areas of cultivation, lead to eutrophication of the still rather oligotrophic water. An increase in plant production within the swamp will probably lead to a still lower oxygen content in the water and add to the accumulation of litter. All these influences lead to acceleration in the naturally occurring process of the swamp that is being filled in. In contrast to upland and, to a lesser degree, montane forest, however, there are little in the way of direct threats to the swamp, as it is not utilizable, e.g. for agriculture.

\section{CONCLUSIONS AND RECOMMENDATIONS}

An effort has been made to collect and collate as much of the existing data on Rawa Aopa as has proved possible. This effort also clearly revealed large gaps in the available knowledge of this unique and interesting part of Sulawesi. As development in the areas surrounding the swamp makes rapid progress, it seems important to fill these gaps. As the present Author sees it, there are three major directions of research to be followed:

- Water regime:- Water input, water regime, and relations with the rivers of the same catchment area, are not yet fully understood. Monitoring of water levels, and at least punctual recordings of water flowing into and out of the swamp, are required for better understanding of this system.

- Vegetation:- The vegetation map given in this report only shows a rough distribution of the main vegetation-types in the swamp. As it has been drawn mainly from aerial photographs dating from 1982, before the recent influx of settlers, it already needs extensive updating. Furthermore, detailed botanical studies are needed, as the species present in this area are only very incompletely known.

- Fauna:- With the exception of the avifauna, the animal life in the Rawa Aopa is virtually unknown. Much detailed investigation of different animal groups needs to be done to obtain a detailed picture of the ecological role of this swamp.

Field-work for this report revealed some important differences between the two main parts of the swamp. Only the southwestern part belongs to the National Park, while the northeastern part has no protection status. However, the distribution of habitats is very unequal between these two parts. While in the south-west there are large surfaces of swamp-forest of types that are absent from the other part, this latter in turn seems to be more important as a wetland, and for instance as habitat of water-birds. If Rawa Aopa is considered as a part of a possible touristic development of south-east Sulawesi (and there is undoubtedly a potential for such a development), the northeastern part of the swamp would probably prove to be more attractive for visitors. Therefore it is recommended to consider the inclusion of this part of the swamp in the National Park.

However, the most urgent need lies in the establishment of a comprehensive inventory and management plan for the whole catchment area. Demographic aspects and agricultural development have to be taken into consideration, together with the abiotic and biotic conditions, in order to attain the development of this interesting region on a sustainable basis. But even without planning, it is obvious that conservation of the forests on the surrounding hills is the most important prerequisite, together with (and indeed for) protection of the villages and cultures and the long-term conservation of the swamp.

\section{SUMMARY}

Rawa Aopa is a large swamp in South-East Sulawesi, Indonesia - the only major peat-swamp in this mainly mountainous island. Its vegetation and fauna are still quite poorly known. The existing information is summarized here. With the creation of new villages as part of Indonesia's transmigration programme, the human population in this area has increased very rapidly. Pressure on natural resources - especially soils and forests - is increasing, and primary forests are dwindling rapidly. This in turn increases the threats to Rawa Aopa, as erosion in its catchment area inevitably leads to a rapid silting up of the swamp. The swamp has a potential as a source of food (fish and sago) and income (rattan and other products), and it might to some degree become a tourist attraction. 
From a scientific point of view, the gaps in the knowledge about water-regime, vegetation, and fauna, ought to be remedied. In order to attain sustainable utilization of this area, a thorough plan ought to be made for the whole catchment of Rawa Aopa. The most important measure to take is the protection of the forests covering the hills and the surroundings of the swamp. Also important very widely is the protection of soils. Furthermore, it is recommended to include the northern part of the swamp in the already-existing Rawa Aopa-Watumohai National Park.

\section{REFERENCES}

AnON. (1978). Laporan Survai Inventarisasi Satwa di Rawa Opa dan Sekitarnya Sulawesi Tenggara. Direktorat Perlindungan dan Pengawetan Alam, Bogor, Indonesia: 33 pp. (typescript).

ANON. (1983). Inventarisasi flora dan fauna di Rawa Aopa, Sulawesi Tenggara. Sub Balai Perlindungan dan Pelestarian Alam, Sulawesi Tenggara, Indonesia: $32 \mathrm{pp}$. (typescript).

ANON. (1985a). Laporan inventarisasi flora di Taman Nasional Rawa Aopa-Watumohai, Propinsi Sulawesi Tenggara. Proyek Pembinaan Suaka Alam dan Hutan Wisata, Taman Nasional Rawa Aopa-Watumohai 1984-1985, Sulawesi, Indonesia: 45 pp. (typescript).

ANON. (1985b). Rencana Karya Lima Tahun Taman Nasional Rawa Aopa 1985-1990. Fakultas Kehutanan, Universitas Gadjah Mada, Yogyakarta, Indonesia: $92 \mathrm{pp}$. (typescript).

Anon. (1987). Rencana Karya Tahunan Calon Taman Nasional Rawa Aopa Watumohai. Departemen Kehutanan, Kabupaten Kendari, Sulawesi, Indonesia: 29 pp. (typescript, no longer available for checking).

CLU (1989a). Studi identifikasi perencanaan sistem drainase dataran Wawotobi. (Draft Inception Report.) Citra Lahan Utama, Bandung, Indonesia: (typescript).

CLU (1989b). Analisis Dampak Lingkungan. (Draft Final Report.) Citra Lahan Utama, Bandung, Indonesia: 133 pp. (typescript).

CORNER, E.J.H. (1966). The Natural History of Palms. University of California Press, Berkeley, California, USA: 393 pp., illustr.

Davidson, J. (1987). Strategies for Forest Development in SouthEast Sulawesi. UNDP/IBRD, Kendari, Sulawesi, Indonesia: 119 pp. (typescript).

DEH (Direktion für Entwicklungszusammenarbeit und humanitaere Hilfe) (1989). Entwicklungszusammenarbeit der Schweizerischen Eidgenossenschaft, Jahresbericht 1988. Eidg. Dep. für ausw. Angelegenheiten (EDA), Bern, Switzerland: 36 pp., illustr.

EWI (1988a). Southeast Sulawesi Irrigation Project: Feasibility Study for Konaweha Right Bank Subproject. EWI, Zurich, CECI, Taiwan, and BIEC, Bandung, Indonesia: (typescript).

EWI (1988b). Agro-institutional Profile: Project Benefit Monitoring for the South-East Sulawesi Irrigation Project (LahumbutiAsera). EWI, Zürich, Switzerland and LBDS, Jakarta, Indonesia: (typescript).

EWI (1988c). Agro-economic Profile: Project Benefit Monitoring for the South-East Sulawesi Irrigation Project (LahumbutiAsera). EWI, Zürich, Switzerland, and LBDS, Jakarta, Indonesia: (typescript).

EWI (1989). Southeast Sulawesi Irrigation Project (LahumbutiAsera), Feasibility Study. EWI, Zürich, CECI, Taiwan, and BIEC, Bandung, Indonesia: (typescript).

FAO (1982). National Conservation Plan for Indonesia. Vol. VI: Sulawesi. FAO, Bogor, Indonesia: [not available for checking].
Franke, W. (1981). Nutzpflanzenkunde. Thieme, Stuttgart, Germany: ix +470 pp., illustr.

Goodwin, H.A. \& Holloway, C.W. (1978). IUCN Red Data Book, Vol. 1: Mammalia. IUCN, Morges, Switzerland.

Groves, G.P. (1976). The origin of the mammalian fauna of Sulawesi (Celebes). Z. Saeugetierk., 41, pp. 201-16.

HARYONO, S.K. (1985). Indigenous crops need to be explored. P. 179 in Proceedings of the International Symposium on SouthEast Asian Plant Genetic Resources (Eds K.L. MEHRA \& S. SASTRAPRAOJA), held in Jakarta, 20-24 August 1985. Bogor, Indonesia: 211 pp., illustr.

HENDERSON, H.F. \& WELCOMME, R.L. (1974). The Relationship of Yield to Morpho-edaphic Index and Numbers of Fishermen in African Inland Fisheries. FAO, Rome, Italy: CIFA Occ. Paper No. 1, pp. 1-19.

HONEGGER, R.E. (1968). IUCN Red Data Book, Vol. 3: Amphibia and Reptilia. IUCN, Morges, Switzerland.

JACOBS, M. (1978). Preliminary Report on a First Botanical Exploration of the Opa Swamp and Surrounding Forests in S.E. Sulawesi. Rijksherbarium, Leiden, The Netherlands: $25 \mathrm{pp}$. (unpublished manuscript).

KANTOR STATISTIK KANDARI (1989). Penduduk Sulawesi Tenggara Hasil Registrasi Penduduk Akhir Tahun 1988. Kantor Statistik Prov. Sulawesi Tenggara, Kendari, Indonesia: $48 \mathrm{pp}$.

KondRASHIN, A.V.\& RASHID, K.M. (1987). Epidemiological Considerations for Planning Malaria Control in South-East Asia Region. WHO, New Delhi, India: xii + 411 pp.

LEDEC, G. \& GoOdLAND, R. (1988). Wildlands. Their Protection and Management in Economic Development. The World Bank, Washington, DC, USA: xxii + 278 pp.

LEVINE, J. (1981). Tolaki Farming Systems in Kecamatan Wawotobi of Sulawesi Tenggara: Preliminary Results. SESTADP Occ. Paper No. 3, [not available for checking].

MacKinnon, J. (1988). Field Guide to the Birds of Java and Bali. Gadjah Mada University Press, Yogyakarta, Indonesia: xiii + 390 pp., illustr.

MacKinnon, J. \& K. (1986). Review of the Protected Areas System in the Indo-Malayan Realm. IUCN and UNEP: iv + 284 pp.

MYERS, N. (1988). Tropical forests: much more than stocks of wood. J. Trop. Ecol., 5(2), pp. 209-21.

SeTIADY, I.F. (Ed.) (1979). Survey Penyakit Menular dan Air Minum di Proyek-Proyek Transmigrasi, Sulawesi Tenggara. Direktorat Jenderal P3.M. dan Direktorat Jenderal Transmigrasi, Kendari, Sulawesi, Indonesia: (typescript). [Not available for checking.]

Stresemann, E. (1939-41). Die Voegel von Celebes. J. Orn., 87 (1939), pp. 299-425

J. Orn., 88 (1940), pp. 1-135, pp. 389-487

J. Orn., 89(1941), pp. 1-102.

STUERCHLER, D. (1981). Endemiegebiete tropischer Infektionskrankheiten. Huber, Bern, Switzerland: 246 pp., illustr.

UNEP (1987). The State of the World Environment. United Nations Environment Programme, Nairobi, Kenya: xi $+76 \mathrm{pp}$.

WELCOMME, R.L. (1979). Fisheries Ecology of Floodplain Rivers. Longman, London \& New York: $315 \mathrm{pp}$.

WhitMore, T.C. (1977). Palms of Malaya. Oxford University Press, Kuala Lumpur, Malaysia: xv + 132 pp., illustr.

WhitMORE, T.C. (1984). Tropical Rain Forests of the Far East. Clarendon Press, Oxford, England, UK: 352 pp., illustr.

Whitten, A.J., Mustafa, M. \& Henderson, G.S. (1987). The Ecology of Sulawesi. Gadjah Mada University Press, Yogyakarta, Java, Indonesia: xxi +777 pp., illustr.

ZWAHLEN, R. (1989). Environmental Evaluation Study: Annexe 5 to Wawotobi Drainage Improvement Study. EWI, Zürich, CECI, Taiwan, and BIEC, Bandung: $101 \mathrm{pp}$. illustr. (typescript). 